\title{
Editorial
}

\section{HIV Infection on the Rise among Chinese College Students}

\author{
Chengjun Sun, PhD* \\ School of Management and Economics, Kunming University of Science and Technology, 253, Xuefu Road, Kunming, Yunnan 650093, China

\section{"Corresponding author} \\ Chengjun Sun, PhD \\ Assistant Professor, School of Management and Economics, Kunming University of Science and Technology, 253 Xuefu Road, Kunming, Yunnan 650093, China \\ E-mail: cjunsun@gmail.com
}

\section{Article information}

Received: April 21 ${ }^{\text {st }}, 2018$; Accepted: April $21^{\text {st }}$ 2018; Published: April $21^{\text {st }}, 2018$

\section{Cite this article}

Sun C. HIV infection on the rise among Chinese college students. HIVIAIDS Res Treat Open J. 20I8; 5(I): e3-e4. doi: I0.17/40/HARTOJ-5-e0I2

$\mathrm{F}$ rom the early 1980s when it was identified in 2017, the hu- man immunodeficiency virus (HIV) has infected an estimated 78 million people around the world, causing an estimated 35 million acquired immune deficiency syndrome (AIDS)-related deaths. ${ }^{1,2}$ In China, as of April 30, 2017, the nation reported that 699,471 people were living with HIV/AIDS with 291,198 AIDS patients and 216,727 AIDS caused deaths. ${ }^{3}$

Young people are gradually becoming one of the most affected groups by HIV/AIDS. ${ }^{4}$ Data from the China Center for Disease Control and Prevention (China CDC) showed that between 2011 and 2015 the average annual growth rate of HIV infection in people aged 15 to 24 in China was 35\%. Between January and October 2015, more than 14,000 people in China were infected with HIV, $65 \%$ of which were college students. ${ }^{5}$ Empirical data continuously shows that in China, college students have become a high-risk group for HIV infection.

Four characteristics of HIV infection for Chinese college students are summarized as follows:

1. The number of infection is growing fast;

2. Infected subjects are mostly male;

3. The main mode of transmission is sexual communication;

4. The main infection route is the male homosexual transmission.

Statements below are considered the main factors leading to HIV infection of college students:

1. Correct, systematic and comprehensive sexual knowledge and sex consciousness are absent in the growth education of adolescents;

2. There is a serious separation between knowledge and practice among college students. They don't know how to perform safe sex to protect themselves and their partners during sexual intercourse;

3. Excessively open sexual concepts and homosexual behaviors, and the absence of self-protection consciousness contribute to the HIV epidemic among college students.

College students are the cornerstone of modern societies. To fulfill HIV prevention, it is imperative to implement health education and behavioral interventions for young students. For instance, the Ministry of Education issued a guideline suggesting that higher education institutions set up public courses on health education, to teach students about sex and reproductive health. ${ }^{6}$ At present, the correct use of condoms is considered one of the most effective ways in HIV prevention. It should be useful to promote condom use through its free distribution, and make HIV testing more accessible on campuses. ${ }^{7}$

\section{ACKNOWLEDGEMENT}

The author acknowledges financial support from the project of KMUST for Fostering Talents in provincial level (KKSY20160 8050) and the project of Yunnan Education Department (2016ZZX055). The author would like to acknowledgement Kunming University of Science and Technology research facility and support.

\section{REFERENCES}

1. Avert. Global HIV and AIDS statistics. 2017. Web site. https:// www.avert.org/global-hiv-and-aids-statistics. Accessed April 20, 2018.

2. UNAIDS. Fact Sheet-Latest Statistics on the Status of the AIDS Epidemic. Geneva, Switzerland, 2017. Web site. http:// www.unaids.org/en/resources/fact-sheet. Accessed April 20, 
2018.

3. Update on the AIDS/STD epidemic in China in April, 2017. CHINESE Journal of AIDS \& STD. 2017; 23(06): 473.

4. WHO. WHO/UNAIDS launch new standards to improve adolescent care. 2015. Web site. http://www.who.int/mediacentre/ news/releases/2015/health-standards-adolescents/en/. Accessed April 20, 2018.

5. Tang H, Li Y, Wang X. Analyzing the status of HIV/AIDS infection of college students and its countermeasures. Chinese Health
Service Management. 2017; 34(06): 474-476.

6. Ministry of Education. University HIV reporting mechanism will be established in China [In Chinese]. 2015. Web site. http:// www.moe.gov.cn/jyb_xw/s5147/201508/t20150811_199281. html. Accessed August 24, 2017.

7. Chinese National Center for AIDS/STD Control and Prevention. HIV prevention programs in universities 2016 [In Chinese]. 2016. Web site. http://ncaids.chinacdc.cn/fzdt/zxdt/201704/ t20170424_142296.htm. Accessed August 21, 2017. 